\title{
Efektivitas Pengendalian Intern Piutang Usaha dengan Menggunakan Pendekatan COSO
}

\author{
Iswahyudi $^{1}$, Dwi Prastowo Darminto ${ }^{2}$ \\ 1,2, Universitas Pancasila , Jakarta, Indonesia
}

\author{
INFO ARTIKEL \\ JEL Classification : \\ M10, M41
}

Keywords :

internal control, accounts

receivable, COSO

Approach

\begin{abstract}
The The purpose of this study was to determine the effectiveness of internal control of receivables at PT. Phar Indonesia is based on five components of COSO, namely the control environment, risk assessment, control activities, information and communication, and monitoring. The analytical method uses descriptive qualitative on the accounts receivable internal control questionnaire which refers to the COSO framework on the components of internal control. (Supported by SPSS Software Version. 24). The results showed that the risk assessment component was less effective, while the environmental control component, the control activity component, the information and communication component, and the monitoring component were effective.
\end{abstract}

\begin{abstract}
ABSTRAK
Tujuan penelitian ini adalah untuk mengetahui efektivitas pengendalian intern piutang pada PT. Phar Indonesia berdasaarkan lima komponen COSO, yaitu lingkungan pengendalian, penilaian risiko, aktivitas pengendalian, informasi dan komunikasi, dan pemantauan. Metode analisis menggunakan deskriptif kualitatif terhadap kuesioner pengendalian intern piutang usaha yang mengacu pada kerangka kerja COSO pada komponen-komponen pengendalian intern. (Program SPSS Versi. 24). Hasil penelitian menunjukkan bahwa komponen penilaian risiko kurang efektif, sedangkan pengendalian lingkungan intern, pengendalian aktivitas intern, informasi intern dan komunikasi intern, dan pengawasan intern perusahaan semua efektif.
\end{abstract}

\section{Pendahuluan}

Perusahaan dalam menjalankan kegiatan usaha lebih difokuskan pada peningkatan volume penjualan barang atau jasa yang ditawarkan perusahaan, dimana seorang manajer harus menentukan suatu kebijakan untuk mencapai fokus tersebut. Kebanyakan perusahaan melakukan peningkatan volume penjualan dengan cara memberikan pelayanan kredit yang lebih mudah, tetapi dalam kebijakan ini sudah pasti perusahaan menanggung risiko peningkatan piutang yang mungkin gagal bayar. Dalam pemberian kredit harus mempertimbangkan banyak hal dari perusahaan yang akan meminjam seperti historis kegiatan usaha dan status kesehatan keuangan perusahaan itu, supaya tidak mendapatkan kesulitan dalam melakukan kolektifitas piutang yang disebabkan tidak 
adanya dana karena pendapatan menurun atau bahkan bangkrut yang dialami perusahaan peminjam. Dengan kemudahan kredit tersebut akan dimanfaatkan customeruntuk melakukan pembelian karena dirasa sangat membantu dalam mendukung pendanaan perusahaannya tetapi menimbulkan nilai piutang yang cukup tinggi bagi perusahaan yang dipinjaminya dan tugas manajer mencarikan jalan keluar dalam melakukan pengendalian serta pengelolaan piutang yang efektif.

Perusahaan dalam menjalankan kegiatan usaha lebih difokuskan pada peningkatan volume penjualan barang atau jasa yang ditawarkan perusahaan, dimana seorang manajer harus menentukan suatu kebijakan untuk mencapai fokus tersebut. Kebanyakan perusahaan melakukan peningkatan volume penjualan dengan cara memberikan pelayanan kredit yang lebih mudah, tetapi dalam kebijakan ini sudah pasti perusahaan menanggung risiko peningkatan piutang yang mungkin gagal bayar. Dalam pemberian kredit harus mempertimbangkan banyak hal dari perusahaan yang akan meminjam seperti historis kegiatan usaha dan status kesehatan keuangan perusahaan itu, supaya tidak mendapatkan kesulitan dalam melakukan kolektifitas piutang yang disebabkan tidak adanya dana karena pendapatan menurun atau bahkan bangkrut yang dialami perusahaan peminjam. Dengan kemudahan kredit tersebut akan dimanfaatkan customer untuk melakukan pembelian karena dirasa sangat membantu dalam mendukung pendanaan perusahaannya tetapi menimbulkan nilai piutang yang cukup tinggi bagi perusahaan yang dipinjaminya dan tugas manajer mencarikan jalan keluar dalam melakukan pengendalian serta pengelolaan piutang yang efektif.

Sutrisno (2007:57) menyatakan bahwa "Pengelolaan piutang yang efektif menunjukan perputaran piutang setiap tahun mengalami peningkatan dan pengumpulan piutang selalu tepat dengan target diharapkan perusahaan." Muslich (2003:108-109) menyatakan bahwa "Pengelolaan piutang yang efektif akan memberikan pengaruh terhadap tingkat profitabilitas perusahaan." Perusahaan Phar Indonesia mengalami permasalahan dalam penagihan piutangnya. Pada empat tahun terakhir secara berturutturut perusahaan mengalami peningkatan piutang tak tertagih yang cukup signifikan yang berakibat pada menurunnya laba perusahaan. Berdasarkan laporan piutang tak tertagih perusahaan selama empat tahun terakhir secara berturut-turut mengalami kenaikan. Hal ini menggambarkan lemahnya sistem manajemen perusahaan dalam melakukan pengendalian atas piutang perusahaan selama periode kenaikan tersebut. Berikut ini data mengenai piutang usaha perusahaan:

Tabel 1.1

Daftar Piutang Tak Tertagih Periode 2015 - 2018

\begin{tabular}{cc}
\hline Tahun & Persentase \\
\hline 2018 & $8 \%$ \\
2017 & $4.99 \%$ \\
2016 & $2.82 \%$ \\
2015 & $2.17 \%$ \\
\hline
\end{tabular}

\section{Sumber: \\ Data Sekunder Laporan KeuanganPT. PharIndonesia}

Dengan data yang dikemukakan diatas, penulis tertarik untuk melakukan penelitian untuk mengetahui lebih dalam atas penyebab terjadinya kenaikan piutang tak tertagih perusahaan yang karena ini merupakan salah satu factor meningkat tiap tahunnya. Penelitian ini dilakukan pada sektor piutang, yang dapat menunjang pendapatan perusahaan. Selain itu pentingnya perputaran piutang yang baik dapat mengatasi masalah likuiditas perusahaan khususnya kas, sehingga mempermudah perusahaan dalam menjalankan kegiatan produktifitasnya. Perputaran piutang merupakan sebuah ukuran seberapa sering piutang usaha berubah menjadi kas dalam setahun dimana dengan ketentuan kredit, piutang usaha harus berputar sedikit diatas 12 kali dalam setahun (Riyanto, 2004:90). Sesuai latar belakang masalah yang terjadi, penulis bermaksud melakukan penelitian dengan judul "Evaluasi pengendalian intern piutang pada PT. Phar Indonesia. Pengelolaan piutang baik akan memberikan dampak yang baik dalam perputaran aset perusahaan. Dalam konsep ini 
peneliti menggunakan kerangka penelitian yang mengacu pada konsep yang diterapkan COSO.

Penulis telah merumuskan pokok permasalahan dalam penelitian tentang pengendalian intern piutang pada PT. Phar Indonesia berdasarkan pendekatan COSO.

1. Apakah lingkungan pengendalian intern piutang usaha PT. Phar Indonesia sudah efektif?

2. Apakah penilaian risiko intern piutang usaha PT. Phar Indonesia sudah efektif ?

3. Apakah aktivitas pengendalian intern piutang usaha PT. Phar Indonesia sudah efektif?

4. Apakah informasi dan komunikasi intern piutang usaha PT. Phar Indonesia sudah efektif?

5. Apakah Pemantauanintern piutang usaha PT. Phar Indonesia sudah efektif?

Tujuan dari penelitian pada perusahaan PT. Phar Indonesia yaitu:

1. Untuk mengetahui efektivitas lingkungan pengendalian intern piutang usaha pada PT. Phar Indonesia.

2. Untuk mengetahui efektivitas penilaian risiko intern piutang usaha pada PT. Phar Indonesia.

3. Untuk mengetahui efektivitas aktivitas pengendalian intern piutang usaha pada PT. Phar Indonesia.

4. Untuk mengetahui efektivitas informasi dan komunikasi intern piutang usaha pada PT. Phar Indonesia.

5. Untuk mengetahui efektivitas pemantauan / monitoring intern piutang usaha pada PT. Phar Indonesia.

\section{Telaah Teori dan Pengembangan Hipotesis}

\section{Piutang}

Menurut Pernyataan Standar Akuntansi Keuangan (PSAK) no. 43, piutang adalah jenis pembiayaan dalam bentuk pembelian dan atau pengalihan piutang atau tagihan jangka pendek suatu perusahaan yang berasal dari transaksi usaha.Piutang menurut PSAK merupakan aset keuangan yang dicatat berdasarkan biaya perolehan diamortasi. Ketika akan dievaluasi, jika nilai piutang tersebut signifikan diantara nilai aset lain yang dicatat berdasarkan biaya perolehan diamortasi, maka akan dievaluasi penurunan nilainya secara kolektif bersama aset lain yang dicatat berdasarkan biaya perolehan diamortisasi.

Menurut Jusup (2001:52) mendefinisikan "piutang merupakan hak untuk menagih yang sah sejumlah uang dari si penjual kepada si pembeli akibat dari adanya transaksi penjualan kredit." Menurut Mulyadi (2001:257-258) "piutang merupakan klaim kepada pihak lain atas uang, barang, atau jasa yang dapat diterima dalam jangka waktu satu tahun, atau dalam satu siklus kegiatan perusahaan." Piutang umumnya disajikan di neraca dalam dua buah kelompok, piutang usaha, dan piutang non usaha.

\section{Pengendalian Intern}

Menurut Arens, Elders, dan Beasley (2015:340) Sistem pengendalian internal terdiri atas kebijakan dan prosedur yang dirancang untuk memberikan manajemen kepastian yang layak bahwa perusahaan telah mencapai tujuan dan sasaran manajemen.

Beberapa komponen pengendalian intern yang dinyatakan Committee of Sponsoring Organizations of the Treadway Commission / COSO, terbagi menjadi 5 komponen pengendalian:

\section{Pengendalian lingkungan intern}

Pengendalian lingkungan internadalah menentukan bentuk organisasi, menciptakan efek awareness pada SDMnya. Pengendalian lingkungan internialah salah satu pondasi dari keseluruhan komponen internal control yang di dalamnya terdapat discipline and structure. Komponen ini tersedia panduan-panduan untuk organisasi serta memberikan efek awareness bagi para anggota dalam organisasi.Integritas, nilai etik, kompetensi, komitmen, direksi, audit,dan human resources merupakan suatu faktor-faktor yang memberikan pengaruh (influence) pada pengendalian lingkungan intern.

Menurut Arens, Elder, dan Beasley (2015:346) ada beberapa faktor yang mempengaruhi lingkungan pengendalian, diantaranya:

1. Integritas dan nilai etika

2. Komitmen terhadap kompetensi.

3. Partisipasi dewan direksi dan komisaris atau komite audit.

4. Filosofi dan gaya operasi manajemen.Manajemen, melalui aktivitas-aktivitas yang dilakukannya, 
memberikan sinyal yang sangat jelas kepada karyawan mengenai signifikasi pengendalian internal.

5. Struktur organisasi.

6. Kebijakan perihal sumber daya manusia.

\section{Penilaian Risiko}

Risk assesment ialah menganalisis atau mengidentifikasi atas risiko yang bernilai relevan dengan maksud untuk mencapai suatu goal (tujuan), metode untuk menetapkan tata cara mengelola risiko. Implementasi risk assessment dalam laporan keuangan ialah melakukan standarisasi dalam penganalisisan, identifikasi, pengorganisasian, dan risk management terkait penciptaan laporan keuangan (financial reporting).Risk management yang berhubungan dengan laporan keuangan dimulai dari aktivitas pencatatan, aktivitas proses, aktifitas ikhtisar serta laporan data financial. Berdasarkan rumusan COSO, bahwa penilaian risiko melibatkan proses yang dinamis dan interaktif untuk mengidentifikasi dan menilai risiko terhadap pencapaian tujuan. Risiko itu sendiri dipahami sebagai suatu kemungkinan bahwa suatu peristiwa akan terjadi dan mempengaruhi pencapaian tujuan entitas, dan risiko terhadap pencapaian seluruh tujuan dari entitas ini dianggap relatif terhadap toleransi risiko yang ditetapkan.

\section{Pengendalian aktivitas intern}

Pengendalian aktivitas intern adalah suatu aktivitas yang memberikan arahan-arahan yang mendukung terjaminya pelaksanaan kegiatan intern perusahaan terlaksana dengan baik dan sesuai SOP. Pengendalian aktivitas intern merupakan suatu prosedur atau kebijakan yang dibuat untuk mengatasi risikorisiko sehingga mempermudah organisasi perusahaan dalam mencapai tujuannya. Pengendalian aktivitas intern mempunyai tingkatan-tingkatan implementasi dalam penerapan ditingkat fungsi maupun organisasi. Biasanya pengendalian aktivitas intern yang sekiranya memiliki relevansi atas audit bisa dijadikan kebijakan maupun sebagai prosedur terkait dengan peninjauan atas pemisahaan fungsi, kontrol fisik, olah data informasi, dan kinerja pengendalian.Berikut kategori-kategori pengendalian aktivitas intern:

1. Kontrol olah data informasi (pemrosesan).
a. Application control
b. Sistem otorisasi akurat
c. Aktualisasi pencatatan dan dokumentasi
d. Independensi pemeriksaan
e. Pengendalian umum

2. Pemisahan Tugas
a. Pengendalian Fisik
b. Telaah kinerja

Menurut Arens, Elder, dan Beasley (2015:236) meyatakan bahwa, "Aktivitas pengendalian merupakan kebijakan dan prosedur selain yang telah dimasukan dalam ke-empat komponen lainnya, yang membantu untuk meyakinkan bahwa tindakan-tindakan yang penting telah dilakukan untuk mengatasi risiko-risiko dalam mencapai tujuan organisasi."

\section{Informasi Dan Komunikasi}

Informasi dan komunikasi adalah pengidentifikasian, penangkapan, dan pertukaran informasi dalam suatu bentuk dan waktu yang memungkinkan orang melaksanakan tanggung jawab mereka. Sistem informasi yang relevan dalam pelaporan keuangan yang meliputi sistem akuntansi yang berisi metode mengidentifikasikan, menggabungkan, menganalisa, klasifikasi, mencatat, dan melaporkan transaksi serta menjaga akuntabilitas aset dan kewajiban. Komunikasi meliputi penyediaan deskripsi tugas individu dan tanggung jawab berkaitan dengan struktur pengendalian intern dalam pelaporan keuangan. Auditor harus memperoleh pengetahuan memadai tentang sistem informasi yang relevan dengan pelaporan keuangan untuk memahami:

1. Golongan transaksi dalam operasi entitas yang signifikan bagi laporan keuangan.

2. Bagaimana transaksi tersebut dimulai.

3. Catatan akuntansi, informasi pendukung, dan akun tertentu dalam laporan keuangan yang tercakup dalam pengolahan dan pelaporan transaksi.

4. Pengolahan akuntansi yang dicakup sejak saat transaksi dimulai sampai dengan dimasukkan ke dalam laporan keuangan, termasuk alat elektronik yang digunakan untuk mengirim, memproses, memelihara, dan mengakses informasi. 


\section{Pemantauan (Monitoring)}

Pemantauan adalah proses yang menentukan kualitas kinerja pengendalian intern sepanjang waktu. Pemantauan mencakup penentuan desain dan operasi pengendalian tepat waktu dan pengambilan tindakan koreksi. Proses ini dilaksanakan melalui kegiatan yang berlangsung secara terus menerus, evaluasi secara terpisah, atau dengan berbagai kombinasi dari keduanya. Berdasarkan AICPA karakteristik sistem pengendalian internal yang baik adalah sebagai berikut:

1. Tujuan pengendalian akutansi tergantung pada kompetensi dan integritas personal, independensi fungsi yang diberikan, dan pemahaman mereka tentang prosedur yang telah ditentukan.

2. Pemisahan fungsi yang cukup. Adanya pemisahan fungsi yang jelas atas fungsi yang berlainan untuk tujuan pengendalian internal. Pemisahaan fungsi tersebut adalah dengan menempatkan orang yang berbeda dalam suatu posisi.

3. Transaksi dibuat sesuai dengan bukti yang independen yang membutuhkan otorisasi, dimana otorisasi diberikan oleh orang yang berwewenang dan transaksi sesuai dengan masa otorisasi.

4. Transaksi dicatat dalam jumlah dan periode akutansi pada saat transaksi tersebut terjadi dan diklasifikasikan dalam akun yang tepat.

5. Perolehan aset harus dibatasi dengan otorisasi seseorang.

6. Aset yang ada harus dibandingkan dengan catatan akuntansinya.

Menurut Hery (2011:50) Mengendalian internal atas piutang usaha diawali dengan melakukan evaluasi atas kelayakan kredit debitur. Setiap penjualan kredit yang dilakukan oleh calon pembeli haruslah diuji atau dievaluasi terlabih dahulu kelayakan kreditnya. Bagian penjualan tidak boleh merangkap bagian kredit. Persetujuan pemberian kredit hanya boleh dilakukan oleh manajer kredit. Manajer penjualan tidaklah memiliki otorisasi atau wewenang untuk menyetujui proposal kredit pelanggan. Harus adanya pemisahan fungsi antara bagian persetujuan kredit, bagian penjualan, bagian pencatatan (akuntansi), dan bagian penagihan.
Kerangka konseptual di bawah ini menggambarkan bahwa pengelolaan piutang usaha dilakukan melalui pengendalian intern terhadap piutang usaha dengan mengacu pada model Committee of Sponsoring Organizations of the Treadway Commission / COSO, sehingga diharapkan dengan adanya pengendalian internal dapat meningkatkan kinerja perusahaan.

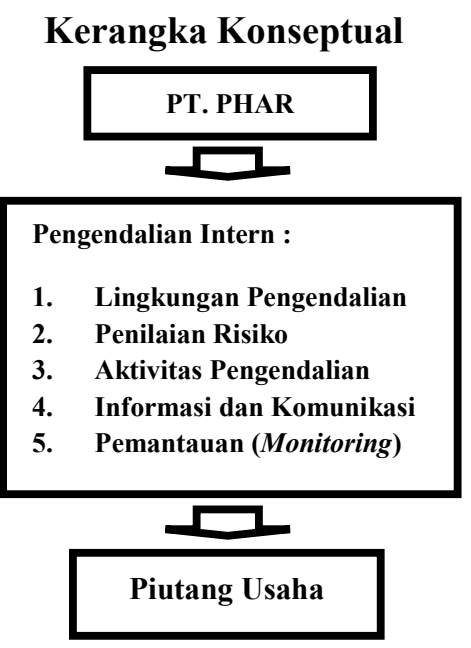

Sumber: Data Diolah

\section{Metode Penelitian}

Model penelitian ini ialah deskriptif kualitatif. Menurut teori Sugiono (2016:53) juga mengemukakan penelitian deskriptif kualitatif sebagai metode penelitian yang berlandaskan pada filsafat post positivisme, digunakan untuk meneliti pada kondisi objek alamiah, dimana peneliti adalah sebagai instrumen kunci, teknik pengumpulan data dengan triangulasi, analisis data bersifat induktif atau kualitatif, dan hasil penelitian kualitatif lebih menekankan makna daripada generalisasi.

Dimana melakukan penyebaran kuesioner dan wawancara dalam mendapatkan data yang diperlukan. Diawali dengan pralapangan seperti administrasi dan membuat RPP yang selanjutnya pengerjaan di lapangan dengan melakukanpretest, pelaksanaan RPP, dan posttest.

"Populasi adalah wilayah generalisasi yang terdiri dari objek atau subjek yang mempunyai kualitas dan karakteristik tertentu yang ditetapkan oleh peneliti untuk dipelajari dan kemudian ditarik kesimpulannya." (Sugiyono, 2016:80) Berdasarkan pendapat di atas, maka yang menjadi populasi dalam penelitian ini 
adalah 10 orang karyawan yang mempunyai tugas dalam pekerjaanya berhubungan dengan pengelolaan dan pengendalian piutang di PT. Phar Indonesia.Menurut Sugiyono (2016:81) "Sampel adalah bagian dari jumlah dan karakteristik yang dimiliki oleh populasi tersebut." Dengan pernyataan di atas penulis mengambil seluruh sampel dari total populasi, yaitu 10 orang responden. Peneliti telah menentukan sampel dari perusahaan PT. Phar Indonesia dengan kriteria-kriteria yang sangat signifikan sehingga jawaban yang nanti didapatkan sudah cukup untuk menyelesaikan rumusan masalahnya.

Dasar pemilihan 10 karyawan yang dijadikan sampel sesuai kriteria yang dibutuhkan:

1. Karyawan yang dijadikan sampel merupakan karyawan yang mulai bekerja sejak 2013 dan masih bekerja sampai 2019.

2. Karyawan yang dijadikan sampel mempunyai andil dalam melakukan pengelolaan piutang.

3. Karyawan yang dijadikan sampel mengetahui semua informasi tentang piutang perusahaan, seperti transaksi penjualan, pencatatan, dan manajemen piutang.

4. Karyawan yang dijadikan sampel mempunyai posisi departemen / devisi yang berkaitan dengan piutang.

5. Karyawan yang dijadikan sampel memiliki wewenang dalam membuat suatu prosedur maupun kebijakan dalam mengelola piutang usaha perusahaan.

Menurut Sugiyono (2016:38), variabel penelitian adalah "Suatu atribut atau sifat atau nilai dari orang, obyek atau kegiatan yang mempunyai variasi tertentu yang ditetapkan oleh peneliti untuk dipelajari dan kemudian ditarik kesimpulannya"
Tabel 3.1

Operasional Variabel

\begin{tabular}{|c|c|}
\hline DIMENSI & INDIKATOR \\
\hline $\begin{array}{l}\text { 1. Lingkungan } \\
\text { Pengendalian }\end{array}$ & $\begin{array}{ll}\text { a. Praktik dan Kebijakan } \\
\text { Manajemen dalam penjualan } \\
\text { kredit. }\end{array}$ \\
\hline $\begin{array}{l}\text { (Control } \\
\text { Environment) }\end{array}$ & $\begin{array}{l}\text { b. Integritas dan Nilai Etik. } \\
\text { c. Gaya Manajemen dan Gaya } \\
\text { Operasi dalam pelaksanaan } \\
\text { kegiatan sesuai SOP. } \\
\text { d. Komitmen terhadap kopetensi } \\
\text { karyawan. } \\
\text { e. Direksi }\end{array}$ \\
\hline & $\begin{array}{lll}\text { a. } & \text { Prinsip } \\
& \text { Organisasi. }\end{array}$ \\
\hline (Risk Assesment) & $\begin{array}{l}\text { b. Reward } \\
\text { c. Sanksi } \\
\text { d. Tunjangan risiko kerja. } \\
\text { e. Training Personel. }\end{array}$ \\
\hline
\end{tabular}

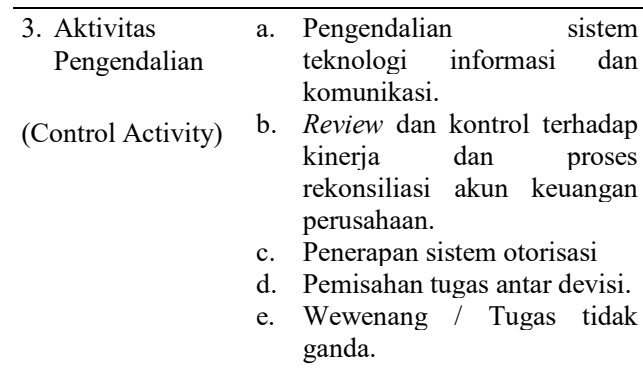

\begin{tabular}{|c|c|}
\hline $\begin{array}{l}\text { (Informasi and } \\
\text { Communication) }\end{array}$ & $\begin{array}{l}\text { a. Intelegensi review } \\
\text { competitor. } \\
\text { b. Pengolahan data akutansi } \\
\text { termasuk dengan yang } \\
\text { menggunakan alat elektronik } \\
\text { (seperti komputer dan } \\
\text { electronic data interchange). } \\
\text { c. Informasi ter-update. } \\
\text { d. pencatatan yang tepat dan } \\
\text { akurat. } \\
\text { e. Informasi yang mudah } \\
\text { diakses. }\end{array}$ \\
\hline $\begin{array}{l}\text { 5. Pemantauan } \\
\text { (Monitoring) }\end{array}$ & $\begin{array}{l}\text { a. Saran perbaikan. } \\
\text { b. Pengambilan tindakan } \\
\text { koreksi. } \\
\text { c. Eksistensi Pelanggan. }\end{array}$ \\
\hline Sumber : & $\begin{array}{l}\text { d. Pengamanan dan pemantauan } \\
\text { saldo akun keuangan. }\end{array}$ \\
\hline $\begin{array}{l}\text { Commite of } \\
\text { Sponsoring of }\end{array}$ & e. Evaluasi dan Survei Cutomer. \\
\hline $\begin{array}{l}\text { Organization } \\
\text { (COSO) dalam } \\
\text { Internal Control- } \\
\text { Integrated } \\
\text { Framework }\end{array}$ & Abdul Halim (2015 : $214-221)$ \\
\hline
\end{tabular}

Sumber: Data Diolah 
Metode penelitian yang digunakan peneliti adalah metode deskriptif kualitatif. Sugiono (2016:53) juga mengemukakan penelitian deskriptif kualitatif sebagai metode penelitian yang berlandaskan pada filsafat post positivisme, digunakan untuk meneliti pada kondisi objek alamiah, dimana peneliti adalah sebagai instrumen kunci, teknik pengumpulan data dengan triangulasi, analisis data bersifat induktif atau kualitatif, dan hasil penelitian kualitatif lebih menekankan makna daripada generalisasi. Berikut dua metode pengumpulan data yang dilakukan oleh peneliti:

Pengertian data primer menurut Sugiyono (2016:137) adalah sumber data yang langsung memberikan data kepada pengumpul data. Berikut metode pengumpulan data primer yang dilakukan penulis:

\section{Kuesioner}

Peneliti mendapatkan data yang diperlukan dengan alat bantu kuesioner untuk mempermudah mendapatkan data yang dibutuhkan. Peneliti menyebarkan kuesioner kepada beberapa karyawan PT. Phar Indonesia yang sudah ditetapkan sebelumnya sebagai sampel.

2. Wawancara

Dimana data didapat dengan melakukan wawancara kepada para karyawan perusahaan yang memiliki kaitan dengan data yang dibutuhkan. Ini dilakukan untuk memberikan jawaban lebih kuat untuk mendukung hasil jawaban kuesioner.

Data sekunder menurut Sugiyono (2016:137) yaitu, sumber data yang tidak langsung memberikan data kepada pengumpul data, misalnya lewat orang lain atau lewat dokumen. Pada penelitian ini peneliti mendapatkan data tentang laporan keuangan perusahaan khususnya piutang melalui audit eksternal yang mengaudit perusahaan tersebut atas izin pihak perusahaan. Data ini berupa dokumen laporan keuangan 2015-2018.

Proses pengembangan instrumen penelitian terdiri dari dua bagian yaitu uji validitas dan uji reliabilitas yang digunakan untuk menguji tiap item pertanyaan yang terdapat pada angket yang dibuat oleh peneliti. Apabila item pertanyaan sudah valid dan reliabel maka item pertanyaan pada angket tersebut sudah bisa digunakan untuk mengumpulkan data. Pengujian validitas dan reliabilitas akan dilakukan setelah angket disebarkan kepada responden. Penyebaran jumlah item uji angket pengendalian intern piutang perusahaan Phar Indonesia sejumlah 25 item.

Uji validitas instrumen dilakukan untuk menunjukan keabsahan dari instrumen yang akan dipakai pada penelitian. Menurut Sugiyono (2015:203) instrumen yang valid berarti alat ukur yang digunakan untuk mendapatkan data (mengukur) itu valid, dengan kata lain instrumen tersebut dapat digunakan untuk mengukur apa yang seharusnya diukur. Alat ukur dapat dikatakan valid jika benar-benar sesuai dan menjawab secara cermat tentang variabel yang akan diukur. Validitas juga menunjukkan sejauh mana ketepatan pernyataan dengan apa yang dinyatakan sesuai dengan koefisien validitas. Penghitungan uji validitas ini menggunakan bantuan Statistical Package for the Social Science (SPSS) dan Microsoft Office Excel. Setelah diperoleh, kemudian dibandingkan dengan dengan tingkat kepercayaan $\alpha=0.05$ dengan

$$
\begin{aligned}
\text { Degree Of Freedom }(\mathrm{df}) & =\mathrm{N}-2 \\
& =10-2 \\
& =8 \\
\text { Tabel r Sig } 0.05 \mathrm{~N}(8) \quad & =0.5494
\end{aligned}
$$

Jika $>0.5494$ maka item tersebut dinyatakan valid, dan jika $<0.5494$ maka item tersebut dinyatakan tidak valid. Bahwa rumus yang digunakan untuk mengukur validitas instrumen adalah Korelasi Pearson Product Moment:

\section{Rumus Validitas:}

$$
r_{y y}=\frac{N \sum X Y-\left(\sum X\right)\left(\sum Y\right)}{\sqrt{\left\{N \sum X^{2}-\left(\sum X\right)^{2}\right\}\left\{N \sum Y^{2}-\left(\sum Y\right)^{2}\right\}}}
$$

$\mathrm{X} \quad=$ Skor yang diperoleh subyek dari seluruh item

$\mathrm{Y} \quad=$ Skor total yang diperoleh dari seluruh item

$\Sigma \mathrm{X}=$ Jumlah skor dalam distribusi $\mathrm{X}$

$\Sigma \mathrm{Y} \quad=$ Jumlah skor dalam distribusi $\mathrm{Y}$

$\Sigma \mathrm{X} 2$ = Jumlah kuadrat dalam skor distribusi $\mathrm{X}$

$\Sigma Y 2=$ Jumlah kuadrat dalam skor distribusi $\mathrm{Y}$ 
$\mathrm{N} \quad=$ Banyaknya responden

Uji reliabilitas dilakukan untuk mengetahui ketetapan suatu instrumen (alat ukur) di dalam mengukur gejala yang sama walaupun dalam waktu yang berbeda. Menurut Sugiyono (2015:203) "Reliabilitas instrumen yaitu suatu instrumen yang bila digunakan beberapa kali untuk mengukur objek yang sama, maka akan menghasilkan data yang sama". Tinggi rendahnya reliabilitas instrumen ditunjukan oleh suatu angka yang disebut koefisien reliabilitas. Jika suatu instrument dipakai dua kali untuk mengukur gejala yang sama dan hasil pengukurannya yang diperoleh konsisten, instrumen itu reliabel. Untuk menguji reliabilitas instrumen dalam penelitian ini, menggunakan koefisien reliabilitas Alfa Cronbach (Arikunto, 2006:196) yaitu:

$$
r_{11}=\left(\frac{k}{k-1}\right)\left(1-\frac{\sum \sigma_{3}^{2}}{\sigma_{1}^{2}}\right)
$$

Keterangan :

dimana

$$
\begin{array}{ll}
\mathrm{r}_{11} & =\text { Reliabilitas Instrumen } \\
\mathrm{k} & =\text { Banyaknya butir pertanyaan } \\
\Sigma_{\mathrm{b}}{ }^{2} & =\text { Jumlah varians butir } \\
\sigma^{2} & =\text { Varians total }
\end{array}
$$

Hasil hitung r-11 dibandingkan dengan rtabel pada $\alpha=0,05$ dengan kriteria kelayakan jika r-11 > r-tabel berarti dinyatakan reliable.

Untuk memudahkan dalam melakukan analisis data yang telah diperoleh dari responden, data tersebut ditabulasikan sesuai dengan jawaban responden pada angket kedalam tabel, kemudian dihitung perolehan skornya, dan selanjutnya dianalisis. Perhitungan dilakukan dengan menggunakan rumus yang dikemukakan oleh Kountur (2005:16) sebagai berikut:

$$
\mathrm{P}=\frac{f}{n} \times 100 \%
$$

Keterangan :

$$
\begin{aligned}
& \text { P : Persentase Skor } \\
& \text { n : Jumlah Total Skor } \\
& \text { f : Jumlah Skor Berdasarkan Alternatif } \\
& \text { Jawaban }
\end{aligned}
$$

Untuk menafsirkan besarnya skor yang diperoleh dari hasil tabulasi data, di dalam penelitian ini digunakan penafsiran dengan kriteria yang dikemukakan oleh Sugiyono (2013:150) yaitu

\begin{tabular}{ccc}
\hline Persentase Interval & Nilai & Keterangan \\
& & \\
\hline $0-20$ & TE & Tidak Efektif \\
$21-40$ & KE & Kurang Efektif \\
$41-60$ & CE & Cukup Efektif \\
$61-80$ & E & Efektif \\
$81-100$ & SE & Sangat Efektif \\
\hline
\end{tabular}

Tabel 3.2 Persentase Interval

Sumber: Sugiyono (2013:150)

\section{Hasil Penelitian dan Pembahasan}

\section{Hasil Penelitian}

Dalam penelitian ini penulis telah menetapkan 10 sampel responden dari keseluruhan populasi. Responden yang dipilih memiliki jangka waktu bekerja di perusahaan mulai dari 2013-2019, dimana mereka ikut andil dalam menentukan kebijakan dan mengetahui seluruh informasi pengendalian intern piutang perusahaan selama beberapa tahun tersebut.

Berikut data berdasarkan jabatan atau pekerjaan yang memiliki informasi lengkap dengan masalah penelitian :

\section{Tabel 4.1 Data Responden}

\begin{tabular}{lll}
\hline No & Jabatan & Jumlah Orang \\
\hline 1. & Financial Control & 1 Orang \\
2. & Financial Accounting & 1 Orang \\
3. & CS (Counter Services) & 1 Orang \\
4. & A/R Admin & 1 Orang \\
5. & MS (Marketing Services) & 4 Orang \\
6. & Debt Devision & 2 Orang \\
\hline
\end{tabular}

Sumber: Data Diolah

\section{Skala Likert}

Skala likert adalah skala yang digunakan untuk mengukur persepsi, sikap atau pendapat seseorang atau kelompok mengenai sebuah peristiwa atau fenomena sosial, berdasarkan definisi operasional yang telah ditetapkan oleh peneliti. Skala ini merupakan suatu skala psikometrik yang biasa diaplikasikan dalam angket dan paling sering digunakan untuk riset yang berupa survei, termasuk dalam penelitian survei deskriptif. Berikut skala yang digunakan dalam pemberian skor untuk masing-masing butir pertanyaan:

1. Sangat Setuju (5) 
2. Setuju (4)

3. Ragu-ragu (3)

4. Kurang Setuju (2)

5. Tidak Setuju (1)

\section{Validitas}

Pengujian ini dilakukan untuk menguji kesahihan setiap item pernyataan dalam mengukur variabelnya. Pengujian validitas dalam penelitian ini dilakukan dengan cara mengkorelasikan skor masing-masing pernyataan item yang ditujukan ke pada responden dengan total skor untuk seluruh item.

Teknik korelasi yang digunakan untuk menguji validitas butir pernyataan dalam penelitian ini adalah korelasi Pearson Product Moment. Apabila nilai koefisien validitas butir item pernyataan yang sedang diuji lebih besar dari r-kritis, maka dapat disimpulkan bahwa item pernyataan tersebut merupakan konstruksi (construct) yang valid.

Degree Of Freedom (df) $=\mathrm{N}-2$

$$
\begin{aligned}
& =10-2 \\
& =8
\end{aligned}
$$

Tabel r Sig $0.05 \mathrm{~N}(8) \quad=0.5494$

Pada tabel 4.2 di bawah terlihat bahwa seluruh item pernyataan memiliki koefisienvaliditas yang lebih besar dari r-kritis 0.5494 sehingga item-item tersebut layak digunakan sebagai alat ukur dalam penelitian. Adapun hasil uji validitas kuesioner untuk variabel yang diteliti disajikan pada tabel berikut :
Tabel 4.2

Validitas Kuesioner

\begin{tabular}{lcc}
\hline Item Pernyataan & $\begin{array}{c}\text { Koefisien } \\
\text { Validitas }\end{array}$ & Keterangan \\
\hline Item Pernyataan 1 & 0.7019 & Valid \\
Item Pernyataan 2 & 0.6883 & Valid \\
Item Pernyataan 3 & 0.7203 & Valid \\
Item Pernyataan 4 & 0.8323 & Valid \\
Item Pernyataan 5 & 0.6321 & Valid \\
Item Pernyataan 6 & 0.8223 & Valid \\
Item Pernyataan 7 & 0.7709 & Valid \\
Item Pernyataan 8 & 0.6939 & Valid \\
Item Pernyataan 9 & 0.8188 & Valid \\
Item Pernyataan 10 & 0.7757 & Valid \\
Item Pernyataan 11 & 0.6752 & Valid \\
Item Pernyataan 12 & 0.6583 & Valid \\
Item Pernyataan 13 & 0.5788 & Valid \\
Item Pernyataan 14 & 0.6157 & Valid \\
Item Pernyataan 15 & 0.6321 & Valid \\
Item Pernyataan 16 & 0.7673 & Valid \\
Item Pernyataan 17 & 0.7496 & Valid \\
Item Pernyataan 18 & 0.6883 & Valid \\
Item Pernyataan 19 & 0.6133 & Vald \\
Item Pernyataan 20 & 0.6772 & Valid \\
Item Pernyataan 21 & 0.8743 & Valid \\
Item Pernyataan 22 & 0.8188 & Valid \\
Item Pernyataan 23 & 0.5922 & Valid \\
Item Pernyataan 24 & 0.6772 & Valid \\
Item Pernyataan 25 & 0.8503 & Valid \\
\hline Sumber: Data Diolah
\end{tabular}

Sumber: Data Diolah

\section{Uji Reliabilitas}

Pengujian reliabilitas dilakukan terhadap butir pernyataan yang termasuk dalam kategori valid. Pengujian realiabilitas dilakukan dengan cara menguji coba instrumen sekali saja. kemudian dianalisis dengan menggunakan metode alpha cronbach. Kuesioner dikatakan andal apabila koefisien realiabilitas bernilai positif dan lebih besar dari pada 0.5494. Adapun hasil dari uji reliabilitas adalah sebagai berikut:

Tabel 4.3 Reliabilitas

\begin{tabular}{llll}
\hline $\begin{array}{l}\text { Jumlah } \\
\text { Item } \\
\text { Pernyataan }\end{array}$ & $\begin{array}{l}\text { Koefisien } \\
\text { Reliabilitas }\end{array}$ & r-kritis & Keterangan \\
\hline 25 Item & 0,9450 & 0,5494 & Reliabel \\
\hline
\end{tabular}

Sumber: Data Diolah

\section{Deskripsi Hasil Penelitian}

Teknik analisis statistik deskriptif bertujuan untuk menjelaskan mengenai keseluruhan data yang dikumpulkan dengan memaparkan, mengelompokkan dan mengklasifikasikan ke dalam tabel distribusi frekuensi yang kemudian diberikan penjelasan. Berikut hasil yang didapatkan dari penelitian ini. 
1. Lingkungan Pengendalian:

$$
\begin{aligned}
& =\frac{(3 \times 10)+(4 \times 32)+(5 \times 8) \times 100 \%}{(5 \times 50)} \\
& =\frac{(30+128+40) \times 100 \%}{250} \\
& =\frac{198 \times 100 \%}{250}=79.2 \% \\
& (\text { Berada diantara kelas } 61-80=\mathrm{E}) \\
& =\underline{\text { Efektif }}
\end{aligned}
$$

\section{Penilaian Risiko:}

$=(1 \times 20)+(2 \times 12)+(3 \times 17)+(4 \times 1) \times 100 \%$ $(5 \times 50)$

$=\frac{(20+24+51+4) \times 100 \%}{250}$

250
$=\frac{99 \times 100 \%}{250}=39.6$

(Berada diantara kelas $21-40=\mathrm{KE}$ )

$=\underline{\text { Kurang Efektif }}$

3. Aktivitas Pengendalian:

$=\frac{(3 \times 14)+(4 \times 29)+(5 \times 7) \times 100 \%}{(5 \times 50)}$

$=(\underline{42+116+35) \times 100 \%}$

$=\frac{193 \times 100 \%}{250}=77.2 \%$

(Berada diantara kelas $61-80=\mathrm{E}$ )

$=\underline{\text { Efektif }}$

4. Informasi dan Komunikasi:

$=\underline{(3 \times 9)+(4 \times 29)+(5 \times 12) \times 100 \%}$ $(5 \times 50)$

$=\underline{(27+116+60) \times 100 \%}$

$$
250
$$

$=\underline{203 \times 100 \%}=81.2$

(Berada diantara kelas $81-100=\mathrm{SE})$

$=\underline{\text { Sangat Efektif }}$

5. Pemantauan (Monitoring):

$=(1 \times 5)+(2 \times 2)+(3 \times 12)+(4 \times 23)+(5 \times 8) \times$ $\underline{100 \%}$

$$
(5 \times 50)
$$

$=\frac{(5+4+36+92+40) \times 100 \%}{250}$

$=\frac{177 \times 100 \%}{250}=70.8$

(Berada diantara kelas $61-80=\mathrm{E}$ )

$=\underline{\text { Efektif }}$

6. Pengendalian Intern Piutang PT. Phar Indonesia:

$=(1 \times 25)+(2 \times 14)+(3 \times 62)+(4 \times 114)+(5 \times 35) \times$ $\underline{100 \%}$

$(5 \times 250)$

$=(\underline{25+28+186+456+175) \times 100 \%}$

$=\underline{870 \times 100 \%}=69.6$

1.250

$($ Berada diantara kelas $61-80=\mathrm{E})$

$=\underline{\text { Efektif }}$

\section{Pembahasan}

Lingkungan Pengendalian telah diterapkan dengan efektif oleh perusahaan, dimana manajemen PT. Phar Indonesia telah mencapai tujuan perusahaan dalam menaikkan laba perusahaan dengan meningkatkan volume penjualan kredit. Integritas dan kompetensi dijunjung tinggi oleh perusahaan dalam pengoperasian kegiatan usahanya. Dalam perekrutan devisi collection perusahaan PT. Phar Indonesia dipilih kandidat yang mempunyai keahlian dan kompetensi yang cukup baik. Direksi selalu mengontrol pengelolaan piutang yang dilakukan perusahaan.

Penilaian risiko PT. Phar Indonesia belum maksimal atau kurang efektif, sehingga berakibat pada kerugian yang dialami perusahaan dalam hal materil maupun non materil. Minimnya insentif atau reward yang diberikan oleh manajemen perusahaan membuat devisi penagihan kurang begitu loyal untuk melaksanakan tugasnya. Perusahaan juga kurang memperhatikan risiko setiap personil yang melakukan penagihan piutang, seperti tidak adanya asuransi kecelakaan dan pencurian yang menunjang keamanan karyawan dalam bekerja.

Marketing Manager tidak memberikan pelatihan sesuai anjuran Credit Analysis kepada devisi Marketing Services dalam menentukan klien yang memiliki potensi memberikan kelancaran pembayaran atas jasa yang diberikan. Marketing Manager hanya mengutamakan volume penjualan untuk meningkat untuk mencapai target yang telah ditentukan perusahaan sebelumnya. Sebagian besar klien yang tidak mampu membayar terjadi karena tidak adanya kebijakan pembatasan kredit. Penentuan risiko hanya efektif pada penerapan sanksi bagi pelanggaran SOP.

Kontrak kerjasama perusahaan dengan klien memiliki beberapa aspek kelemahan, yaitu:

1. Tidak adanya jaminan atas aset klien yang diterima oleh PT. Phar Indonesia apabila klien mengalami kebangkrutan, sehingga tidak mampu membayar kewajibanya.

2. Klien memiliki kuasa apabila mengalami penurunan $50 \%$ penjualan yang terjadi selama masa tayang sponsoring, maka klien mempunyai hak untuk membayar $70 \%$ dari total keseluruhan hutang.

Aktivitas pengendalian yang dilakukan PT. Phar Indonesia sangat efektif dalam beberapa aspek, salah satunya otorisasi piutang yang 
baik. Aktivitas pemisahan fungsi yang dilakukan perusahaan juga sudah maksimal.

Informasi dan komunikasi PT. Phar Indonesia sudah dilaksanakan dengan efektif. Perusahaan mempunyai devisi dalam bidang competitor spy, dimana tugas dari devisi ini melakukan pengamatan pesaing, penelitian produk pesaing dan mengikuti perkembangan perusahaan pesaing. Sistem informasi dan komunikasi perusahaan diolah melalui komputerisasi yang mempermudah dalam pengolahan dan penyajian laporan data. Manajemen memberikan layanan informasi ter-update seputar piutang kepada karyawan, klien atau pihak yang bersangkutan melalui sistem digital yang mudah diakses. Pembuatan dokumentasi transaksi dilakukan dengan cukup baik mulai dari catatan, penomoran, otorisasi serta pengarsipan dokumen dilakukan dengan hati-hati. Manajemen perusahaan selalu mengingatkan pelanggan sebelom tanggal jatuh tempo untuk melakukan pembayar kewajibanya.

Pemantauan (Monitoring) yang dilaksanakan manajemen PT. Phar Indonesia sudah efektif. Auditor internal PT. Phar Indonesia memberikan saran dan usulan dalam menentukan kebijakan akutansi yang baik dalam mengatasi setiap masalah piutang perusahaan. Saldo piutang menjadi perhatian khusus oleh auditor internal dan Finance Controller. Saldo piutang akan terus diawasi dan pengecekan setiap waktu oleh Finance Controler untuk menghindari terjadinya kesalahan hitung ataupun salah catat dengan mengoreksi secara langsung. Perusahaan melakukan pemantauan klien / pelanggan setiap hari untuk memastikan bahwa perusahaan masih beroperasi dan mampu untuk melakukan kewajibannya. Komite audit fokus melakukan pengauditan pada laporan keuangan khususnya pada laporan piutang yang bermasalah.

Dalam pemantauan perusahaan secara keseluruhan sudah cukup baik, tetapi kesalahan hanya pada aspek penentuan pelanggan yang kurang baik dalam pelaksanaannya. Survei penentuan pelanggan yang dilakukan Marketing Services kurang maksimal yang berimbas pada gagalnya penagihan. Marketing Devision lebih mengutamakan target penjualan yang ditetapkan perusahaan dibanding risiko yang dihadapi akibat penjualan kredit yang meningkat.

Hasil dari penelitian yang dilakukan peneliti dengan penyebaran kuesioner berdasarkan hasil perhitungan jawaban dari keseluruhan butir pernyataan menunjukkan secara keseluruhan komponen pengendalian intern piutang perusahaan sudah dilaksanakan dengan efektif, tetapi ada satu komponen pengendalian intern yang masih kurang efektif, yaitu penilaian risiko yang tidak maksimal.

\section{Kesimpulan, Keterbatasan dan Implikasi Hasil Penelitian}

1. Lingkungan pengendalian PT. Phar Indonesia terhadap pengendalian intern piutang perusahaan sudah efektif, hal ini ditandai salah satunya dengan penerapan SOP (standart operating procedures) yang dilakukan dengan baik oleh perusahaan dalam menjalankan kegiatan usahanya.

2. Penilaian risiko terhadap piutang usaha pada PT. Phar Indonesia kurang efektif, sehingga menimbulkan permasalahan piutang tak tertagih. Perusahaan mempunyai sisi positif dalam penentuan risiko hanya pada pemberlakuan sanksi yang ditujukan kepada pelanggar SOP. Berikut pokok permasalahan yang membuat meningkatnya piutang tak tertagih perusahaan:

a. Tidak adanya kebijakan pembatasan kredit yang dilakukan perusahaan dalam menekan klien / pelanggan yang masih memiliki tanggungan sebelumnya, sehingga piutang semakin menumpuk hingga klien tidak mampu untuk melaksanakan kewajibannya.

b. Tidak adanya pelatihan sesuai anjuran Credit Analysis dari Marketing Manager yang diberikan kepada marketing Services dalam menetukan klien yang mempunyai potensi baik dalam pembayaran.

c. Minimnya reward dan insentif yang diberikan kepada devisi penagihan menyebabkan menurunnya loyalitas karyawan dan kurang maksimal dalam penagihan.

d. Debt Devision sangat kawatir dalam melaksanakan penagihan ke lokasi tempat klien maupun dalam 
menyimpan dana hasil penagihan, karena tidak adanya asuransi yang menjamin keselamatan kerja dari ancaman pencurian dan kecelakaan yang mungkin terjadi saat melaksanakan tugas.

e. Dalam pembuatan kontrak kerjasama antara PT. Phar Indonesia dengan klien banyak memiliki kelemahan dalam hal jaminan dan hak kolektif piutang.

3. Aktivitas pengendalian yang dilakukan PT. Phar Indonesia sudah efektif, dimana perusahaan telah melakukan pemisahan fungsi, pemeliharaan sistem komputerisasi, rekonsiliasi saldo piutang, dan otorisasi setiap transaksi yang dilakukan dengan baik dan terkontrol.

4. Informasi dan komunikasi yang dilakukan perusahaan terhadap piutang usaha sangat efektif, hal ini ditandai dengan akses sistem yang cepat dan mudah dalam memperoleh data informasi mengenai piutang usaha yang langsung terhubung dengan pihak-pihak terkait. Manajemen piutang selalu meneruskan informasi yang terbarui setiap saat kepada pihak-pihak terkait. Perusahaan juga memiliki devisi yang sangat penting andilnya dalam perkembangan perusahaan dibidang informasi dan komunikasi, khususnya observasi competitor.

5. Pemantauan (Monitoring) terhadap piutang usaha telah berjalan baik dan efektif. Hal ini dapat dilihat dari pemantauan yang dilakukan perusahaan dalam perkembangan saldo piutang, kebijakan akutansi, dan eksistensi perusahaan klien. Pengawasan yang baik juga ditunjukkan audit internal dalam memberikan saransaran tentang kebijakan akutansi yang baik. Dalam pemantauan yang dilakukan PT. Phar Indonesia memiliki kelemahan hanya pada penentuan pelanggan yang potensial, ini dikarenakan bagian pemasaran hanya mengutamakan pencapaian target penjualan tanpa memikirkan risiko gagal dalam pengoleksian piutang.

Pengendalian intern piutang perusahaan berjalan dengan efektif secara keseluruhan, dimana manajemen PT. Phar Indonesia sudah menerapkan pengendalian sesuai dengan konsep dasar dan prinsip-prinsip pengendalian intern, namun di sisi lain terdapat beberapa prosedur yang belum dijalankan sesuai aturan pegendalian intern yang baik.

Berikut ini saran yang dikemukakan oleh penulis dalam mengatasi permasalahan yang dihadapi PT. Phar Indonesia.

1. Hendaknya perusahaan menerapkan kebijakan pembatasan kredit bagi Customer / klien yang masih memiliki tanggungan hutang sebelumya, dan memberlakukan kembali pemberian kredit setelah hutang sebelomnya terlunasi.

2. Sebaiknya perusahaan memberikan apresiasi atas pencapaian target penagihan kepada Debt Devision berupa reward dan insentif, sehingga memberikan dorongan untuk lebih maksimal lagi dalam melakukan penagihan.

3. Hendaknya perusahaan memperhatikan risiko-risiko yang mungkin timbul kepada Debt Devision yang melakukan penagihan piutang di lapangan, seperti risiko pencurian dan kecelakan kerja. Dengan ini perlunya asuransi sangat membantu meminimalisasi kerugian yang terjadi pada perusahaan maupun bagi personil itu sendiri.

4. Hendaknya perusahaan melakukan revisi pada kontrak kerjasama yang sebelumnya telah dibuat dengan memasukkan poinpoin yang memberikan keuntungan lebih bagi perusahaan dan meminimalisasi risiko bagi perusahaan seperti:

a. Meminta jaminan berupa aset klien yang melakukan pembelian jasa secara kredit sebagai antisipasi tidak terbayarnya piutang.

b. Mengubah kebijakan mengenai pembayaran klien $70 \%$ dengan memberlakukan pembayaran $100 \%$ dari nilai hutang, walaupun kondisi penjualan produk kilen mengalami penurunan selama masa tayang sponsoring dengan alasan biaya produksi tidak dapat terpenuhi dengan pengurangan $30 \%$ dari nilai hutang klien.

5. Sebaiknya Marketing Manager melaksanakan pelatihan kepada bawahanya dalam menentukan pelanggan yang potensial sesuai anjuran dari Credit Analysis, karena bagian tersebut sudah 
melakukan observasi terlebih dahulu dan dapat menentukan klien-klien yang tepat.

6. Marketing Manager sebaiknya tidak hanya mementingkan kepentingan devisinya dalam mencapai target penjualannya, tetapi harus mempertimbangkan risiko yang mungkin terjadi di belakang akibat salah dalam menentukan pelanggan.

\section{Daftar Pustaka}

AICPA. (2006). Statement Of Auditing Standart No 109. American : AU314.41 https://www.aicpa.org/content/dam/aicpa/i nterestareas/centerforauditquality/resource s/caqauditlibrary/downloadabledocuments/ caq-sec-regulations-committee-highlightsform-8k-for-11k.pdf .

Arens, A. A., Elder, R..J., \& Beasley, M. S. (2015). Auditing dan Jasa Assurance (Edisi Kelimabelas, Jilid Satu). Jakarta : Erlangga.

Arikunto. (2006). Prosedur Penelitian Suatu Pendekatan Praktek. Jakarta : PT. Rineka Cipta.

Hery. (2011). Auditing 1 Dasar-dasar Pemeriksaan Akutansi (Cetakan Pertama). Jakarta : Kencana.

Ikatan Akuntan Indonesia. (2013). Exposure Draft Pernyataan Standar Akuntansi Keuangan, Penyajian Laporan Keuangan. Diakses dari: https://staff.blog.ui.ac.id, tanggal : 16 mei 2019.
Jusup, A1. Haryono. (2001). Dasar-dasar Akuntansi (Edisi Kelima, Jilid Satu). Yogyakarta : Badan Penerbit STIE Yaasan Keluarga Pahlawan Negara.

Kountur, Ronny. (2005). Metode Penelitian. Jakarta : PPM.

Mulyadi. (2001). Sistem Akuntansi. Cetakan Ketiga (Edisi Ketiga). Jakarta : Salemba Empat.

Muslich, Mochammad. (2003). Manajemen Keuangan Modern Analisis, Perencanaan dan Kebijakan (Cetakan Ketiga). Jakarta : Gramedia Widiasarana Indonesia.

Riyanto, Bambang. (2004). Dasar-dasar Pembelanjaan Perusahaan (Edisi Keempat, Cetakan Kedelapan). Yogyakarta : Badan Penerbit Fakultas Ekonomi.

Sugiyono. (2013). Metode Penelitian Kuantitatif, Kualitatif dan R\&D. Bandung: Alfabeta CV.

Sugiyono. (2015). Metode Penelitian Pendidikan : Pendidikan Kuantitatif , Kualitatif, dan R\&D. Bandung : Alfabeta $\mathrm{CV}$.

Sugiyono. (2016). Metodologi Penelitian Kuantitatif, Kualitatif, dan R\&D. Bandung : Alfabeta CV.

Sutrisno. (2007). Manajemen Keuangan Teori, Konsep, dan Aplikasi.Yogyakarta : Ekonosi. 
Iswahyudi, Dwi Prastowo Darminto : Efektifitas Pengendalian Intern Piutang, Usaha dengan Menggunakan Pendekatan COSO 